\title{
PENGARUH PENGGUNAAN INFORMASI AKUNTANSI TERHADAP KEBERHASILAN USAHA KECIL MENENGAH (STUDI PADA SENTRA KONVEKSI DI KECAMATAN TINGKIR KOTA SALATIGA)
}

\author{
Alex Wibowo \\ Fakultas Ekonomika dan Bisnis, Universitas Kristen Satya Wacana \\ alexmurni23@gmail.com \\ Elisabeth Penti Kurniawati \\ Fakultas Ekonomika dan Bisnis, Universitas Kristen Satya Wacana \\ bet@staff.uksw.edu
}

\begin{abstract}
Accounting information can be used as a basis for business decisions making. Making the right decision can determine the success of a business. Therefore, accounting information has an important role toward the business success. Based on previous studies, SMEs often face difficulties to apply accounting in their business. However, the SMEs can still run their business. The aim of this study is to prove the effect of accounting information utilization toward the business success of SMEs. The research objects are SMEs on convection center in Tingkir Salatiga, which is one of SMEs center that still exist in Salatiga until now. The sampling method used in this research is purposive sampling, with SMEs that already have accounting information as the criteria, so it can be further investigated regarding the use of the accounting information in the business. The results showed that the accounting information utilization affect the business success in the convection center. Therefore, SMEs should use accounting information as a basis for business decisions making in order to obtain appropriate decision so that support its business success.
\end{abstract}

Keywords: accounting information utilization, SME, business success

\section{PENDAHULUAN}

Peranan akuntansi adalah memberikan informasi sebagai dasar untuk pengambilan keputusan bisnis. Menurut Pinasti (2007), informasi akuntansi dapat menjadi dasar yang andal bagi pengambilan keputusan-keputusan dalam pengelolaan usaha kecil, antara lain keputusan pengembangan pasar, penetapan harga dan lainlain. Pengambilan keputusan yang tepat dapat menentukan keberhasilan dari sebuah usaha. Oleh karena itu, informasi akuntansi memiliki peran yang penting bagi pelaku bisnis dalam mencapai keberhasilan usahanya, termasuk bagi usaha kecil menengah (UKM). 
UKM sering mengalami kesulitan untuk menerapkan akuntansi dalam bisnisnya. Suhairi (2004) menyatakan bahwa praktek akuntansi, khususnya akuntansi keuangan pada UKM di Indonesia masih rendah dan memiliki banyak kelemahan. Kelemahan itu, antara lain disebabkan rendahnya pendidikan, kurangnya pemahaman terhadap Standar Akuntansi Keuangan (SAK) dari manajer atau pemilik dan karena tidak adanya peraturan yang mewajibkan penyusunan laporan keuangan bagi UKM (Suhairi 2004).

Berdasarkan fenomena bahwa praktek akuntansi pada UKM masih rendah, namun sebenarnya informasi akuntansi dapat menjadi dasar bagi pengambilan keputusan bisnis dalam rangka mencapai keberhasilan usaha, maka penelitian ini bertujuan untuk membuktikan secara empiris pengaruh dari penggunaan informasi akuntansi terhadap keberhasilan UKM. Objek penelitian ini adalah UKM pada sentra konveksi di Kecamatan Tingkir Kota Salatiga Provinsi Jawa Tengah. Pemilihan sentra konveksi di Kecamatan Tingkir sebagai objek penelitian dikarenakan sentra ini merupakan salah satu industri yang masih beroperasi di Kota Salatiga. Data menunjukkan bahwa Kecamatan Tingkir memberikan kontribusi Produk Domestik Regional Bruto (PDRB) pada urutan ketiga, yaitu sebesar 24,66 persen dengan tingkat pertumbuhan ekonomi sebesar 4,90 persen (BPS 2012).

\section{KAJIAN PUSTAKA DAN PENGEMBANGAN HIPOTESIS}

\section{Penggunaan Informasi Akuntansi}

Menurut Kamus Besar Bahasa Indonesia, penggunaan merupakan proses, cara, perbuatan menggunakan sesuatu; pemakaian (Depdiknas 2008). Belkaoui (2000) mendefinisikan informasi akuntansi sebagai informasi kuantitatif tentang entitas ekonomi yang bermanfaat untuk pengambilan keputusan ekonomi dalam menentukan pilihan-pilihan diantara alternatif-alternatif tindakan. Dari dua definisi tersebut dapat disimpulkan bahwa penggunaan informasi akuntansi merupakan proses, cara, perbuatan menggunakan dan pemakaian informasi akuntansi untuk pengambilan keputusan ekonomi dalam menentukan pilihan-pilihan diantara alternatif-alternatif tindakan.

Informasi akuntansi juga berguna dalam rangka menyusun berbagai proyeksi (Deswira et al., 2009), misalnya: proyeksi kebutuhan uang kas di masa yang akan datang, mengontrol biaya, mengukur produktivitas, meningkatkan produktivitas dan memberikan dukungan terhadap proses produksi. Informasi akuntansi memungkinkan manajemen untuk mengimplementasikan strategi dan melakukan aktivitas operasional yang diperlukan untuk mencapai tujuan organisasi secara keseluruhan (Wahyudi 2009). Informasi akuntansi merupakan informasi yang digunakan sebagai dasar evaluasi kinerja, sehingga dapat dijadikan tolok ukur dalam memberikan reward atas kinerja manajerial (Susanto 2008). 
Informasi akuntansi pada dasarnya bersifat keuangan dan terutama digunakan untuk tujuan pengambilan keputusan, pengawasan dan implementasi keputusankeputusan perusahaan (Holmes dan Nicholls 1988). Menurut Anthony dan Reece (1995), informasi akuntansi digolongkan menjadi tiga jenis yaitu informasi operasi, akuntansi manajemen dan akuntansi keuangan. Sedangkan Holmes dan Nicholls (1988) dalam Tania (2008), mengklasifikasikan informasi akuntansi dalam tiga jenis yang berbeda menurut manfaatnya bagi para pemakai, yaitu sebagai berikut.

1. Statutory accounting information, merupakan informasi yang harus disiapkan sesuai dengan peraturan yang ada.

2. Budgetary information, yaitu informasi akuntansi yang disajikan dalam bentuk anggaran yang berguna bagi pihak internal dalam perencanaan, penilaian dan pengambilan keputusan.

3. Additional accounting information, yaitu informasi akuntansi lain yang disiapkan perusahaan guna meningkatkan efektifitas pengambilan keputusan manajer.

Konsep informasi akuntansi menurut Anthony dan Reece (1995) serta Holmes dan Nicholls (1988) inilah yang akan digunakan dalam penelitian ini. Oleh karena itu, penggunaan informasi akuntansi mencakup penggunaan informasi operasi, informasi akuntansi manajemen dan informasi akuntansi keuangan yang bermanfaat untuk memenuhi peraturan yang ada, melakukan perencanaan, penilaian dan pengambilan keputusan, serta untuk meningkatkan efektifitas pengambilan keputusan manajer UKM.

\section{Usaha Kecil dan Menengah}

Batasan UKM yang dipergunakan dalam penelitian ini mengacu pada Undang-Undang No. 20 Tahun 2008 tentang Usaha Mikro, Kecil dan Menengah. Usaha kecil adalah usaha ekonomi produktif yang berdiri sendiri, yang dilakukan oleh orang perorangan atau badan usaha yang bukan merupakan anak perusahaan atau bukan cabang perusahaan yang dimiliki, dikuasai atau menjadi bagian baik langsung maupun tidak langsung dari usaha menengah atau usaha besar yang memenuhi kriteria usaha kecil sebagaimana dimaksud dalam undang-undang ini. Usaha menengah adalah usaha ekonomi produktif yang berdiri sendiri, yang dilakukan oleh orang perseorangan atau badan usaha yang bukan merupakan anak perusahaan atau cabang perusahaan yang dimiliki, dikuasai, atau menjadi bagian baik langsung maupun tidak langsung dengan usaha mikro atau usaha besar dengan jumlah kekayaan bersih atau hasil penjualan tahunan sebagaimana diatur dalam undang-undang ini.

Berdasarkan Undang-Undang No. 20 Tahun 2008 tersebut, klasifikasi UKM dapat dibagi berdasarkan kepemilikan aset dan omzet perusahaan yang disajikan dalam Tabel 1. 
Tabel 1

Kriteria UKM

\begin{tabular}{llcc}
\hline \multirow{2}{*}{ No } & \multicolumn{2}{c}{ Kriteria } \\
\cline { 3 - 4 } & \multicolumn{1}{c}{ Aset (Rp) } & \multicolumn{1}{c}{ Omzet (Rp) } \\
\hline 1 & Usaha kecil & $>50$ Juta -500 Juta & $>$ 300 Juta $-2,5$ Miliar \\
2 & Usaha menengah & $>500$ Juta -10 Miliar & $>2,5$ Miliar -50 Miliar \\
\hline \multicolumn{2}{l}{ Sumber: UU No. 20 Tahun 2008 }
\end{tabular}

\section{Keberhasilan Usaha}

Keberhasilan usaha biasanya diidentifikasi dengan membesarnya skala usaha yang dimilikinya, yang bisa dilihat dari volume produksi yang tadinya bisa menghabiskan sejumlah bahan baku per hari meningkat menjadi mampu mengolah bahan baku yang lebih banyak (Haryadi 1998). Menurut Haryadi (1998), kriteria keberhasilan usaha didasarkan pada jumlah karyawan (banyaknya karyawan yang bekerja, rendahnya turn over karyawannya, tingkat lamanya bekerja karyawan dan tingkat pendidikan karyawan) dan peningkatan omzet penjualan (tingkat banyaknya pesanan, tingkat promosi pesanan, tingkat harga yang ditawarkan dan tingkat penghasilan dari penjualan).

Sedangkan menurut Suryana (2003), keberhasilan usaha adalah keberhasilan dari bisnis dalam mencapai tujuannya. Kriteria keberhasilan usaha menurut Suryana (2003) meliputi meningkatnya modal, meningkatnya pendapatan, meningkatnya volume penjualan, meningkatnya output produksi serta meningkatnya tenaga kerja. Keberhasilan usaha dapat dilihat melalui kemampuan bertahan hidup dan semakin berkembangnya suatu perusahaan (Saboet 1994), antara lain dengan adanya peningkatan volume produksi; adanya tambahan tenaga kerja; adanya tambahan alat produksi dengan berharap adanya peningkatan kemampuan produksi serta adanya tambahan modal yang berasal dari laba di tahan.

\section{Nalar Konsep}

Informasi akuntansi digunakan sebagai dasar untuk pengambilan keputusan bisnis, yang sangat bermanfaat dalam merencanakan, mengelola maupun mengevaluasi usaha. Dengan adanya informasi akuntansi, semua kegiatan usaha dapat dikelola dengan baik, sehingga dapat menunjang keberhasilan usaha.

Informasi akuntansi mempunyai pengaruh yang sangat penting bagi pencapaian keberhasilan usaha, termasuk UKM. Penelitian Megginson et al. (2000) (dalam Pinasti 2007), menyatakan bahwa informasi akuntansi mempunyai peran penting untuk mencapai keberhasilan usaha, termasuk bagi usaha kecil. Informasi akuntansi dapat menjadi dasar yang andal bagi pengambilan keputusan-keputusan dalam pengelolaan usaha kecil, antara lain keputusan pengembangan pasar, penetapan harga dan lain-lain (Pinasti 2007). Penelitian Utomo (2010) menyatakan bahwa persepsi dan penggunaan informasi akuntansi berpengaruh terhadap keberhasilan pengusaha kecil. 
Namun di lain pihak, hasil penelitian Pinasti (2001) menunjukkan bahwa para pedagang kecil di pasar tradisional Kabupaten Banyumas tidak menyelenggarakan dan tidak menggunakan informasi akuntansi dalam pengelolaan usahanya. Keputusan-keputusan dalam pengelolaan usaha lebih banyak didasarkan pada informasi-informasi nonakuntansi dan pengamatan sepintas atas situasi pasar (Pinasti 2007).

Berdasarkan hasil penelitian di atas timbul pertanyaan apakah penggunaan informasi akuntasi mempunyai pengaruh terhadap keberhasilan usaha, sehingga dirumuskan hipotesis yang akan diuji dalam penelitian ini sebagai berikut.

H1: Ada pengaruh penggunaan informasi akuntansi terhadap keberhasilan UKM.

Model yang digunakan dalam penelitian ini dapat digambarkan sebagai berikut:

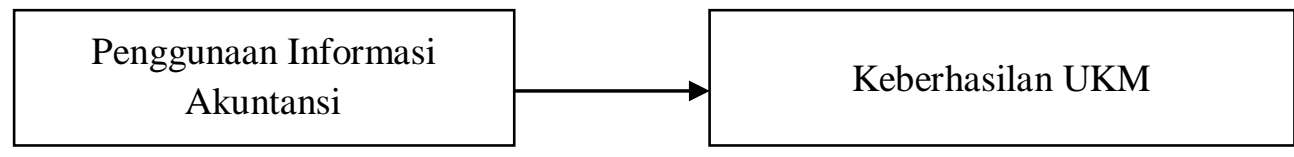

\section{Gambar 1}

Model Penelitian

\section{METODA PENELITIAN}

Populasi dalam penelitian ini adalah pemilik usaha konveksi yang ada di Kecamatan Tingkir Salatiga, yaitu sebanyak 130 pengusaha konveksi (BPS 2012). Sedangkan sampel dalam penelitian ini ditetapkan sebesar 60 pengusaha dengan pengambilan sampel diukur menggunakan formula untuk menentukan ukuran sampel (Yamane 1973 dalam Tania 2008) sebagai berikut:

$n=\frac{N}{N d^{2}+1}$

Dimana:

$\mathrm{N} \quad=$ jumlah sampel

$\mathrm{N} \quad=$ ukuran populasi

$\mathrm{d} \quad=$ tingkat kesalahan pengambilan sampel yang masih dapat ditoleransi $(0,1 \%)$

$n=\frac{130}{130(0,1)^{2}+1}=56,52$ dibulatkan menjadi 60

Metoda pengambilan sampel menggunakan purposive sampling, dengan cara menentukan responden dari populasi yang diperkirakan paling cocok untuk dikumpulkan datanya (Sugiyono 2010). Kriteria pengambilan sampel dalam penelitian ini adalah UKM yang sudah memiliki catatan atas pengelolaan bisnisnya, sehingga lebih lanjut dapat diteliti penggunaan informasi dalam bisnisnya. 
Jenis data yang digunakan dalam penelitian ini adalah data primer. Data primer adalah data yang dikumpulkan langsung dari individu-individu yang diselidiki (Sugiyono 2010). Dalam penelitian ini data primer diperoleh melalui penyebaran kuesioner serta wawancara terhadap para pengusaha konveksi di Kecamatan Tingkir, Salatiga.

Tabel 2

Definisi Operasional dan Indikator Empiris dari Penggunaan Informasi Akuntansi

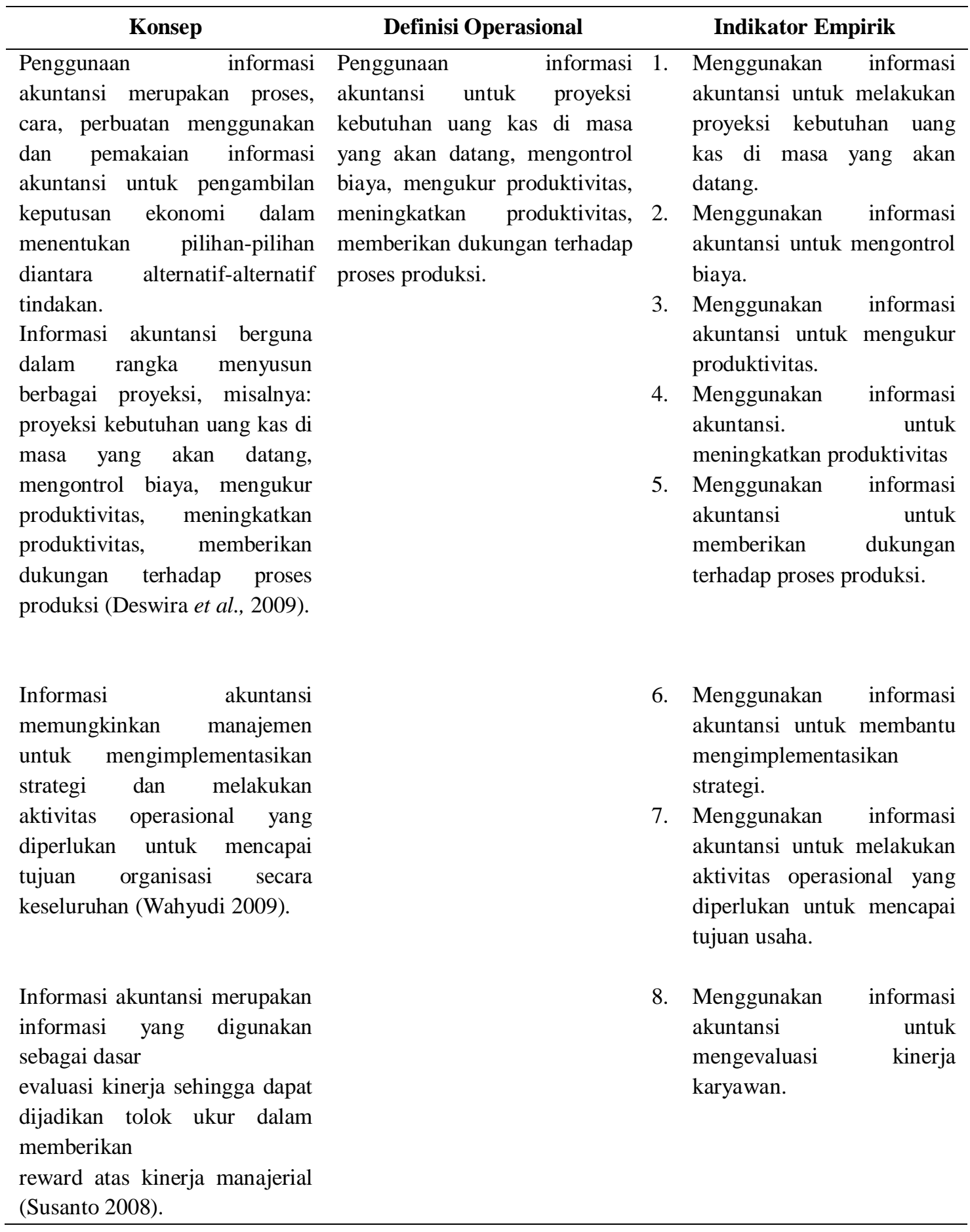


Tabel 2 (Lanjutan)

Definisi Operasional dan Indikator Empiris dari Penggunaan Informasi Akuntansi

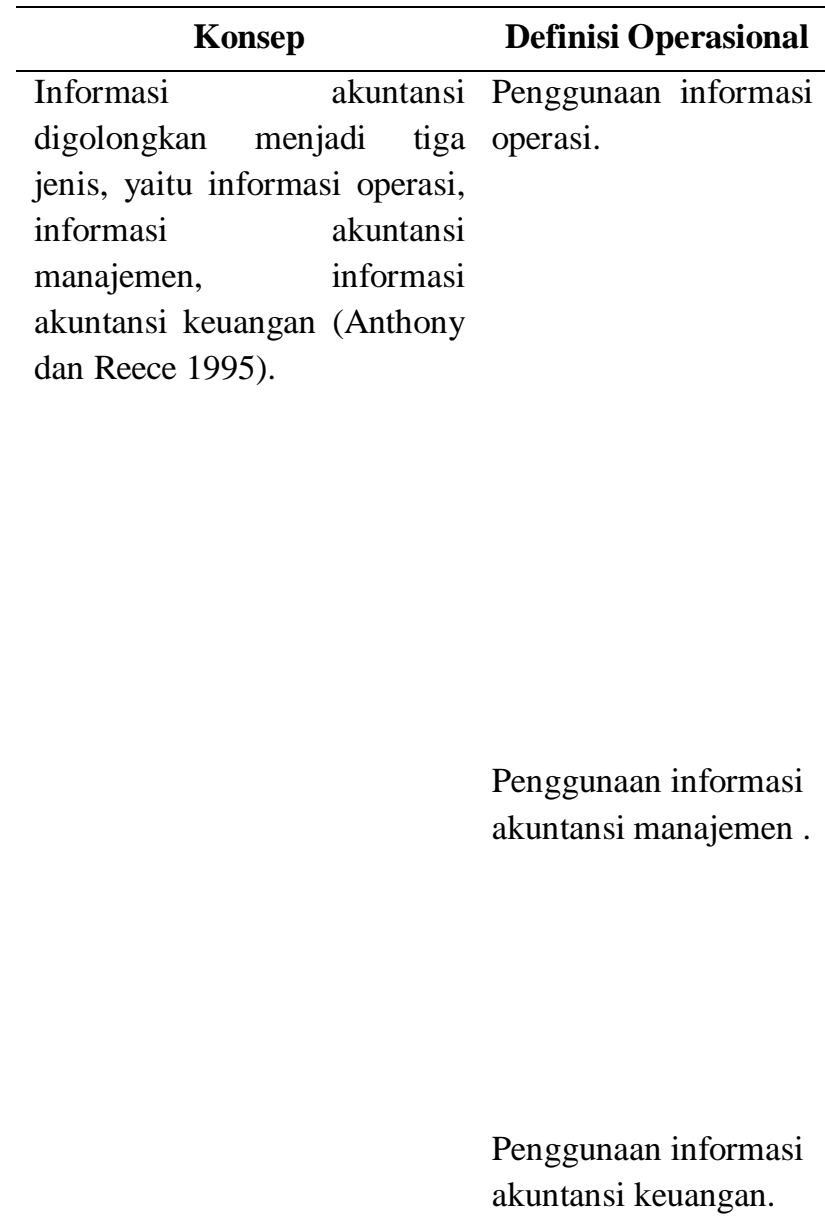

Informasi akuntansi menurut Penggunaan informasi manfaatnya bagi para statutoryaccounting. pemakai, terbagi dalam tiga jenis informasi yang berbeda, Penggunaan informasi yaitu: statutory accounting budgetary. information, budgetary information, additional Penggunaan informasi accounting information additional accounting. (Holmes dan Nicholls (1988) dalam Tania (2008). 
Pertanyaan-pertanyaan yang diajukan kepada para responden diklasifikasikan menjadi 2 (dua) bagian, yaitu bagian pertama tentang penggunaan informasi dan bagian kedua tentang keberhasilan usaha. Penelitian ini menggunakan skala Likert dari skala 1 sampai 5, dimana untuk variabel penggunaan informasi, angka 1 mewakili pernyataan tidak pernah sama sekali dan angka 5 mewakili pernyataan sangat sering. Sedangkan untuk variabel keberhasilan usaha, angka 1 mewakili pernyataan sangat tidak setuju dan angka 5 mewakili pernyataan sangat setuju.

Definisi operasional serta indikator empiris dari masing-masing konsep yang digunakan dalam penelitian ini dijelaskan dalam Tabel 2 dan Tabel 3.

Tabel 3

Definisi Operasional dan Indikator Empiris dari Keberhasilan Usaha

\begin{tabular}{|c|c|c|}
\hline Konsep & Definisi Operasional & Indikator Empirik \\
\hline $\begin{array}{l}\text { Keberhasilan usaha } \\
\text { keberhasilan dari bisnis dalam } \\
\text { mencapai tujuannya (Suryana, } \\
\text { 2003). } \\
\text { Menurut Haryadi (1998), kriteria } \\
\text { keberhasilan usaha didasarkan pada } \\
\text { jumlah karyawan (banyaknya } \\
\text { karyawan yang bekerja, rendahnya } \\
\text { turn over karyawannya, tingkat } \\
\text { lamanya bekerja karyawan, tingkat } \\
\text { pendidikan karyawan) dan } \\
\text { peningkatan omzet penjualan } \\
\text { (tingkat banyaknya order, tingkat } \\
\text { promosi pesanan, tingkat harga } \\
\text { yang ditawarkan, tingkat } \\
\text { penghasilan dari penjualan). } \\
\text { Menurut Suryana (2003), kriteria } \\
\text { keberhasilan usaha menurut } \\
\text { meliputi meningkatnya modal, } \\
\text { meningkatnya } \\
\text { meningkatnya volume penjualan, } \\
\text { meningkatnya output produksi, } \\
\text { serta meningkatnya tenaga kerja. } \\
\text { Menurut Saboet (1994), kriteria } \\
\text { keberhasilan usaha meliputi adanya } \\
\text { peningkatan volume produksi, } \\
\text { adanya tambahan tenaga kerja, } \\
\text { adanya tambahan alat produksi } \\
\text { dengan berharap adanya } \\
\text { peningkatan kemampuan produksi } \\
\text { serta adanya tambahan modal yang } \\
\text { berasal dari laba ditahan. }\end{array}$ & $\begin{array}{l}\text { Meningkatnya modal (Suryana } \\
\text { 2003; Saboet 1994). } \\
\text { Meningkatnya pendapatan } \\
\text { (Suryana 2003). } \\
\text { Meningkatnya volume penjualan } \\
\text { (Suryana 2003). } \\
\text { Meningkatnya jumlah produksi } \\
\text { (Suryana 2003; Saboet 1994). } \\
\text { Meningkatnya jumlah alat produksi } \\
\text { (Saboet 1994). }\end{array}$ & $\begin{array}{l}\text { 1. Usaha mengalami pertambahan } \\
\text { jumlah karyawan. } \\
\text { 2. Usaha mengalami peningkatan } \\
\text { jumlah pesanan (order). } \\
\text { 3. Usaha mengalami peningkatan } \\
\text { promosi pesanan. } \\
\text { 4. Usaha mengalami peningkatan } \\
\text { harga jual. } \\
\text { 5. Usaha mengalami peningkatan } \\
\text { penghasilan dari penjualan. } \\
\text { 6. Usaha mengalami peningkatan } \\
\text { modal. } \\
\text { 7. Usaha mengalami peningkatan } \\
\text { pendapatan. } \\
\text { 8. Usaha mengalami peningkatan } \\
\text { volume penjualan. } \\
\text { 9. Usaha mengalami peningkatan } \\
\text { jumlah produksi. } \\
\text { 10. Usaha peningkatan jumlah alat } \\
\text { produksi. }\end{array}$ \\
\hline
\end{tabular}


Teknik analisis yang digunakan dalam penelitian ini adalah teknik statistik menggunakan alat analisis regresi sederhana. Regresi sederhana digunakan untuk menjelaskan pengaruh antara variabel penggunaan informasi terhadap variabel keberhasilan usaha.

Sebelum melakukan uji regresi sederhana, untuk menguji keabsahan data dilakukan uji validitas dan uji reliabilitas terlebih dahulu. Selanjutnya, dilakukan uji regresi sederhana dengan persamaan sebagai berikut:

$$
Y=\alpha+\beta x+\varepsilon
$$

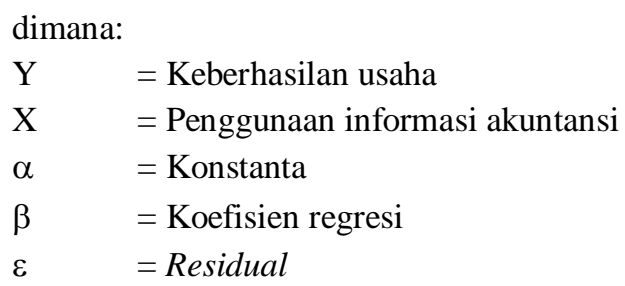

\section{HASIL PENELITIAN DAN PEMBAHASAN}

Karakteristik responden dalam penelitian ini dideskripsikan berdasarkan jenis kelamin, usia, pendidikan terakhir dan lama menjadi pengusaha disajikan dalam Tabel 4. Tabel 4 menunjukkan bahwa, sebagian besar responden adalah berjenis kelamin perempuan, yaitu sebesar 68,33 persen dan laki-laki sebesar 31,67 persen. Hal ini dapat dipahami karena usaha konveksi di Kecamatan Tingkir Salatiga, pada umumnya merupakan usaha yang dikelola ibu rumah tangga dalam rangka membantu kepala rumah tangga untuk menafkahi keluarganya.

Berdasarkan data usia responden, sebagian besar responden berusia di atas 40 tahun. Pada umumnya usaha konveksi di Kecamatan Tingkir Salatiga merupakan usaha yang diwariskan secara turun temurun. Sehingga keterampilan mereka sebagai pengusaha sudah terbina sejak mereka muda. Hal ini dapat dikatakan bahwa pada usia tersebut para responden merupakan pengusaha yang sudah berpengalaman dalam menjalankan bisnisnya.

Berdasarkan data tingkat pendidikan, sebagian besar responden memiliki tingkat pendidikan SMA/sederajat ke bawah. Menurut responden, sebagian besar pengusaha konveksi melanjutkan usaha orang tuanya. Dari kondisi tersebut dapat disimpulkan bahwa untuk melakukan usaha konveksi ini tidak perlu memiliki jenjang pendidikan yang tinggi. Para responden berada di lingkungan bisnis konveksi sejak mereka kecil, sehingga sejak dini mereka telah melihat dan terbiasa dengan bisnis konveksi ini, baik dari usaha orang tuanya maupun dari para tetangganya. Dengan pendidikan wajib 12 tahun atau kurang, asalkan ada kemauan, ulet, serta memiliki keterampilan yang memadai, mereka dapat menjalankan usaha warisan orang tuanya tanpa harus berpendidikan tinggi. 
Tabel 4

Karakteristik Responden

\begin{tabular}{|c|c|c|}
\hline Karakteristik & Jumlah & Prosentase \\
\hline \multicolumn{3}{|l|}{ Jenis Kelamin } \\
\hline Perempuan & 41 & $68,33 \%$ \\
\hline Laki-laki & 19 & $31,67 \%$ \\
\hline Total Jenis Kelamin & 60 & $100,00 \%$ \\
\hline \multicolumn{3}{|l|}{ Usia } \\
\hline Di bawah usia 30 tahun & 6 & $10,00 \%$ \\
\hline Usia 31 tahun s/d usia 40 tahun & 14 & $23,33 \%$ \\
\hline Usia 41 tahun s/d usia 50 tahun & 16 & $26,67 \%$ \\
\hline Di atas usia 50 tahun & 24 & $40,00 \%$ \\
\hline Total Usia & 60 & $100,00 \%$ \\
\hline \multicolumn{3}{|l|}{ Tingkat Pendidikan } \\
\hline SD/Sederajat & 7 & $11,67 \%$ \\
\hline SMP/Sederajat & 13 & $21,67 \%$ \\
\hline SMA/Sederajat & 26 & $43,33 \%$ \\
\hline Diploma & 6 & $10,00 \%$ \\
\hline Sarjana & 8 & $13,33 \%$ \\
\hline Total Tingkat Pendidikan & 60 & $100,00 \%$ \\
\hline \multicolumn{3}{|l|}{ Lama Usaha } \\
\hline$<10$ tahun & 7 & $11,67 \%$ \\
\hline 11 tahun - 15 tahun & 14 & $23,33 \%$ \\
\hline 16 tahun - 20 tahun & 18 & $30,00 \%$ \\
\hline$>20$ tahun & 21 & $35,00 \%$ \\
\hline Total Lama Usaha & 60 & $100,00 \%$ \\
\hline
\end{tabular}

Sumber: data primer diolah, 2013

Berdasarkan data lama usaha, sebagian besar usaha telah berdiri lebih dari 15 tahun. Tingkir Lor adalah sentra konveksi yang telah lama ada sejak Indonesia belum merdeka, responden yang tertuapun tidak tahu persis kapan sentra ini mulai terbentuk. Oleh karena itu, tidak mengherankan jika perusahaan-perusahaan pada sentra ini sebagian besar bukan merupakan perusahaan yang baru berdiri.

Tabel 5 di atas menunjukkan bahwa sebagian besar usaha konveksi di Kecamatan Tingkir Salatiga memiliki aset yang masuk dalam kriteria usaha kecil dengan aset > Rp50 Juta sampai dengan Rp200 Juta. Namun dari sisi omzet sabagian besar usaha termasuk dalam kriteria usaha mikro dengan omzet $\leq$ Rp300 Juta per tahun. 
Tabel 5

Karakteristik Responden Berdasarkan Aset dan Omzet Pertahun

\begin{tabular}{|c|c|c|c|c|c|c|}
\hline Keterangan & Aset & Jumlah & Persentase & Omzet per Tahun & Jumlah & Persentase \\
\hline \multirow[t]{2}{*}{ Mikro } & $\leq 50$ juta & 3 & $5,00 \%$ & $\leq$ Rp. 300 juta & 44 & $73,33 \%$ \\
\hline & $\begin{array}{l}>\text { Rp. } 50 \text { juta s/d } \\
\text { Rp. } 200 \text { juta }\end{array}$ & 45 & $75,00 \%$ & $\begin{array}{l}>\text { Rp. } 300 \text { juta s/d } \\
\text { Rp. } 1,5 \mathrm{M}\end{array}$ & 16 & $26,67 \%$ \\
\hline \multirow[t]{3}{*}{ Kecil } & $\begin{array}{l}>\text { Rp. } 200 \text { juta s/d } \\
\text { Rp. } 350 \text { juta }\end{array}$ & 8 & $13,33 \%$ & & & \\
\hline & $\begin{array}{l}>\text { Rp. } 350 \text { juta s/d } \\
\text { Rp. } 500 \text { juta }\end{array}$ & 4 & $6,67 \%$ & & & \\
\hline & Total & 60 & $100,00 \%$ & Total & 60 & $100,00 \%$ \\
\hline
\end{tabular}

Sumber: data primer diolah, 2013

\section{Penggunaan Informasi Akuntansi oleh Pengusaha UKM}

Tabel 6

Penggunaan Informasi Akuntansi oleh Pemilik UKM

\begin{tabular}{|c|c|c|c|c|c|c|}
\hline Indikator & $\begin{array}{l}\text { Tidak } \\
\text { Pernah }\end{array}$ & $\begin{array}{l}\text { Sekali- } \\
\text { kali }\end{array}$ & $\begin{array}{l}\text { Kadang- } \\
\text { kadang }\end{array}$ & Sering & $\begin{array}{l}\text { Sangat } \\
\text { Sering }\end{array}$ & Total \\
\hline $\begin{array}{l}\text { Melakukan proyeksi kebutuhan uang kas di } \\
\text { masa yang akan datang. }\end{array}$ & $0,00 \%$ & $0,00 \%$ & $23,33 \%$ & $58,33 \%$ & $18,33 \%$ & $100 \%$ \\
\hline Mengontrol biaya dalam menjalankan usaha & $0,00 \%$ & $1,67 \%$ & $10,00 \%$ & $45,00 \%$ & $43,33 \%$ & $100 \%$ \\
\hline Mengukur produktivitas & $0,00 \%$ & $21,67 \%$ & $35,00 \%$ & $36,67 \%$ & $6,67 \%$ & $100 \%$ \\
\hline Meningkatkan produktivitas & $1,67 \%$ & $10,00 \%$ & $16,67 \%$ & $40,00 \%$ & $31,67 \%$ & $100 \%$ \\
\hline $\begin{array}{l}\text { Memberikan dukungan terhadap proses } \\
\text { produksi }\end{array}$ & $1,67 \%$ & $0,00 \%$ & $31,67 \%$ & $33,33 \%$ & $33,33 \%$ & $100 \%$ \\
\hline Mengimplementasikan strategi & $0,00 \%$ & $1,67 \%$ & $26,67 \%$ & $53,33 \%$ & $18,33 \%$ & $100 \%$ \\
\hline $\begin{array}{l}\text { Melakukan aktivitas operasional yang } \\
\text { diperlukan untuk mencapai tujuan usaha }\end{array}$ & $0,00 \%$ & $1,67 \%$ & $8,33 \%$ & $46,67 \%$ & $43,33 \%$ & $100 \%$ \\
\hline Mengevaluasi kinerja karyawan & $1,67 \%$ & $0,00 \%$ & $30,00 \%$ & $38,33 \%$ & $30,00 \%$ & $100 \%$ \\
\hline Mengetahui jumlah produksi setiap hari & $0,00 \%$ & $1,67 \%$ & $28,33 \%$ & $65,00 \%$ & $5,00 \%$ & $100 \%$ \\
\hline Mengetahui jumlah pembelian bahan baku & $0,00 \%$ & $0,00 \%$ & $20,00 \%$ & $45,00 \%$ & $35,00 \%$ & $100 \%$ \\
\hline Mengetahui jumlah pemakaian bahan baku & $0,00 \%$ & $1,67 \%$ & $11,67 \%$ & $41,67 \%$ & $45,00 \%$ & $100 \%$ \\
\hline $\begin{array}{l}\text { Mengetahui penggajian / pengupahan ke } \\
\text { karyawan }\end{array}$ & $1,67 \%$ & $0,00 \%$ & $8,33 \%$ & $46,67 \%$ & $43,33 \%$ & $100 \%$ \\
\hline Mengetahui jumlah penjualan tiap harinya & $0,00 \%$ & $1,67 \%$ & $21,67 \%$ & $56,67 \%$ & $20,00 \%$ & $100 \%$ \\
\hline Merencanakan kegiatan usaha & $0,00 \%$ & $0,00 \%$ & $36,67 \%$ & $30,00 \%$ & $33,33 \%$ & $100 \%$ \\
\hline Mengimplementasi/menjalankan usaha & $0,00 \%$ & $1,67 \%$ & $30,00 \%$ & $33,33 \%$ & $35,00 \%$ & $100 \%$ \\
\hline Mengendalikan usaha & $0,00 \%$ & $0,00 \%$ & $8,33 \%$ & $43,33 \%$ & $48,33 \%$ & $100 \%$ \\
\hline Mengetahui posisi keuangan & $6,67 \%$ & $1,67 \%$ & $28,33 \%$ & $28,33 \%$ & $35,00 \%$ & $100 \%$ \\
\hline Mengetahui kinerja perusahaan & $3,33 \%$ & $1,67 \%$ & $20,00 \%$ & $55,00 \%$ & $20,00 \%$ & $100 \%$ \\
\hline Mengetahui kenaikan atau penurunan modal & $1,67 \%$ & $3,33 \%$ & $28,33 \%$ & $31,67 \%$ & $35,00 \%$ & $100 \%$ \\
\hline $\begin{array}{l}\text { Memenuhi standar peraturan dari bank, } \\
\text { koperasi atau paguyuban }\end{array}$ & $0,00 \%$ & $1,67 \%$ & $25,00 \%$ & $55,00 \%$ & $18,33 \%$ & $100 \%$ \\
\hline Menganggarkan usaha yang mendatang & $0,00 \%$ & $0,00 \%$ & $13,33 \%$ & $41,67 \%$ & $45,00 \%$ & $100 \%$ \\
\hline $\begin{array}{l}\text { Meningkatkan efektifitas pengambilan } \\
\text { keputusan }\end{array}$ & $0,00 \%$ & $0,00 \%$ & $38,33 \%$ & $28,33 \%$ & $33,33 \%$ & $100 \%$ \\
\hline
\end{tabular}

Sumber: data primer diolah, 2013 
Tabel 6 menyajikan penggunaan informasi akuntansi oleh pemilik UKM konveksi di Kecamatan Tingkir Salatiga. Hasil penelitian menunjukkan bahwa pemilik UKM konveksi di Kecamatan Tingkir Salatiga sering (43,33\%) dan sangat sering (30,76 \%) menggunakan informasi akuntansi. Pemilik UKM ini sering menggunakan informasi akuntansi pada umumnya untuk melakukan proyeksi kebutuhan uang kas di masa yang akan datang (58,33\%), mengimplementasikan strategi (53,33\%), mengetahui jumlah produksi setiap hari (65\%), mengetahui jumlah penjualan tiap hari (56,67\%), mengetahui kinerja perusahaan (55\%) dan memenuhi standar peraturan dari bank, koperasi atau paguyuban (55\%).

\section{Keberhasilan Usaha UKM}

Hasil penelitian menunjukkan bahwa pemilik UKM konveksi di Kecamatan Tingkir Salatiga setuju (41,17\%) dan sangat setuju (38,83\%) jika dikatakan usaha mereka mengalami keberhasilan, dengan indikator pesanan pelanggan meningkat (50\%) dan kepemilikan alat produksi meningkat (50\%). Tabel 7 berikut ini menyajikan keberhasilan usaha menurut pemilik UKM konveksi di Kecamatan Tingkir Salatiga.

Tabel 7

Keberhasilan Usaha Menurut Pemilik UKM

\begin{tabular}{lcccccc}
\hline \multicolumn{1}{c}{ Indikator } & $\begin{array}{c}\text { Sangat } \\
\text { Tidak } \\
\text { Setuju }\end{array}$ & $\begin{array}{c}\text { Tidak } \\
\text { Setuju }\end{array}$ & $\begin{array}{c}\text { Ragu- } \\
\text { ragu }\end{array}$ & Setuju & $\begin{array}{c}\text { Sangat } \\
\text { Setuju }\end{array}$ & Total \\
\hline Jumlah karyawan saya meningkat & $0,00 \%$ & $20,00 \%$ & $11,67 \%$ & $58,33 \%$ & $30,00 \%$ & $100 \%$ \\
Pesanan pelanggan saya meningkat & $5,00 \%$ & $1,67 \%$ & $15,00 \%$ & $50,00 \%$ & $28,33 \%$ & $100 \%$ \\
Omzet saya meningkat & $3,22 \%$ & $3,33 \%$ & $15,00 \%$ & $35,00 \%$ & $43,33 \%$ & $100 \%$ \\
Promosi produk saya meningkat & $0,00 \%$ & $1,67 \%$ & $5,00 \%$ & $48,33 \%$ & $45,00 \%$ & $100 \%$ \\
Harga jual produk naik karena kualitas naik & $1,67 \%$ & $11,67 \%$ & $20,00 \%$ & $38,33 \%$ & $28,33 \%$ & $100 \%$ \\
Modal saya bertambah & $3,33 \%$ & $3,33 \%$ & $15,00 \%$ & $35,00 \%$ & $43,33 \%$ & $100 \%$ \\
Pendapatan saya bertambah & $0,00 \%$ & $1,67 \%$ & $6,67 \%$ & $45,00 \%$ & $46,67 \%$ & $100 \%$ \\
Penjualan saya meningkat & $1,67 \%$ & $10,00 \%$ & $20,00 \%$ & $40,00 \%$ & $28,33 \%$ & $100 \%$ \\
Jumlah produksi saya meningkat & $1,67 \%$ & $8,33 \%$ & $5,00 \%$ & $40,00 \%$ & $45,00 \%$ & $100 \%$ \\
Alat produksi saya meningkat & $0,00 \%$ & $1,67 \%$ & $6,67 \%$ & $41,67 \%$ & $50,00 \%$ & $100 \%$ \\
Rata-rata & $\mathbf{1 , 6 7 \%}$ & $\mathbf{6 , 3 3 \%}$ & $\mathbf{1 2 , 0 0 \%}$ & $\mathbf{4 1 , 1 7 \%}$ & $\mathbf{3 8 , 8 3 \%}$ & \\
\hline Sumber: & & & & & &
\end{tabular}

Sumber: data primer diolah, 2013

\section{Uji Validitas dan Reliabilitas}

Hasil uji validitas atas indikator penggunaan informasi akuntansi dan variabel keberhasilan usaha menunjukkan bahwa nilai corrected item-total correlation tiap indikator lebih besar dari 0,30. Hasil uji reliabilitas menunjukkan bahwa semua indikator yang diteliti memenuhi unsur reliabilitas dengan nilai Alpha Cronbach $(\alpha)$ lebih besar dari 0,60. Dengan demikian, maka semua indikator dari penggunaan informasi akuntansi variabel keberhasilan usaha dapat digunakan dalam pengolahan data selanjutnya. 
Tabel 8

Uji Validitas dan Reliabilitas Indikator Penggunaan Informasi Akuntansi

\section{Indikator}

Corrected Item- Alpha

Total Correlation Cronbach

\section{Variabel Penggunaan Informasi Akuntansi}

Melakukan proyeksi kebutuhan uang kas di masa yang akan datang.

Mengontrol biaya dalam menjalankan usaha

0.575

Mengukur produktivitas

Meningkatkan produktivitas

Memberikan dukungan terhadap proses produksi

Mengimplementasikan strategi

0.721

Melakukan aktivitas operasional yang diperlukan untuk mencapai tujuan usaha

Mengevaluasi kinerja karyawan

Mengetahui jumlah produksi setiap hari

Mengetahui jumlah pembelian bahan baku

0.658

Mengetahui jumlah pemakaian bahan baku

Mengetahui penggajian/ pengupahan kekaryawan

Mengetahui jumlah penjualan tiap harinya

Merencanakan kegiatan usaha

Mengimplementasi/menjalankan usaha

Mengendalikan usaha

Mengetahui posisi keuangan

Mengetahui kinerja perusahaan

Mengetahui kenaikan atau penurunan modal

0.780

Memenuhi standar peraturan dari bank, koperasi, paguyuban

Menganggarkan usaha yang mendatang

0.574

Meningkatkan efektifitas pengambilan keputusan

0.808

\section{Variabel Keberhasilan Usaha}

Jumlah karyawan saya meningkat

Pesanan pelanggan saya meningkat

Omset saya meningkat

Promosi produk saya meningkat

Harga jual produksinya meningkat

(karena kualitas produk meningkat)

Modal saya bertambah

Pendapatan saya bertambah

Penjualan saya meningkat

Jumlah produksi saya meningkat

Alat produksi saya (mesin, peralatan) meningkat 0.582

\subsection{2}

Sumber: data primer diolah, 2013 


\section{Uji Hipotesis}

Untuk menguji hipotesis tentang adanya pengaruh penggunaan informasi akuntansi terhadap keberhasilan usaha, digunakan teknik analisis regresi linier sederhana dengan menggunakan aplikasi SPSS (Statistical Product and Service Solution) versi 16.00 , dengan $\alpha=5 \%$. Hasil uji regresi disajikan dalam tabel berikut.

Tabel 11

Hasil Analisis Regresi Pengaruh Penggunaan Informasi Akuntansi Terhadap Keberhasilan Usaha $(\mathbf{N}=60)$

\begin{tabular}{lcccc}
\hline \multicolumn{1}{c}{ Variabel Independen } & Hipotesis & t hitung & Sig. & Keterangan \\
\hline Penggunaan informasi akuntansi & $\mathrm{H} 1$ & 2.436 & 0.018 & Diterima \\
$\mathrm{R}^{2}$ & 0.593 & & & \\
\hline
\end{tabular}

Sumber: olahan SPSS, 2013

Hasil analisis regresi pada tabel di atas menunjukkan bahwa tingkat signifikansi sebesar 0,018 lebih kecil dari 0,05 (5 \%) sehingga hipotesis satu didukung dengan hasil penelitian. Hal ini menunjukkan bahwa variabel penggunaan informasi akuntansi terbukti berpengaruh secara positif terhadap keberhasilan usaha.

\section{Pengaruh Penggunaan Informasi Akuntansi terhadap Keberhasilan Usaha}

Berdasarkan uji hipotesis yang telah dilakukan, penggunaan informasi akuntansi terbukti berpengaruh secara positif terhadap keberhasilan usaha pada UKM sentra konveksi di Kecamatan Tingkir Salatiga. Hasil uji $\mathrm{R}^{2}$ pada uji hipotesis menunjukkan bahwa variabel keberhasilan usaha dapat dijelaskan oleh variabel penggunaan informasi akuntansi sebesar 59,30\%, sedangkan sisanya dijelaskan oleh variabel lain. Hasil penelitian ini mendukung penelitian Megginson et al. (2000) dan Utomo (2010), yang mengungkapkan bahwa informasi akuntansi mempunyai pengaruh yang sangat penting bagi pencapaian keberhasilan usaha. Menurut pengusaha konveksi di Kecamatan Tingkir Salatiga, penggunaan informasi akuntansi dapat digunakan untuk membantu manajemen perusahaan, antara lain untuk melakukan perencanaan serta membantu pengambilan keputusan dalam pengelolaan usaha. Selain itu, informasi akuntansi juga diperlukan ketika mereka hendak mengakses bantuan dari pemerintah atau tambahan modal dari kreditur (bank).

Pada dasarnya para pengusaha konveksi di Kecamatan Tingkir Salatiga sudah mempunyai kebiasaan mencatat hal-hal penting yang berkaitan dengan usahanya, meskipun pada umumnya belum menghasilkan laporan keuangan secara lengkap. Adapun jenis laporan atau catatan akuntansi yang banyak digunakan oleh pengusaha sentra konveksi Kecamatan Tingkir Kota Salatiga adalah laporan atau catatan terkait barang jadi, bahan baku serta penggajian atau pengupahan karyawan (lihat tabel 9). 
Tabel 9

Laporan/Catatan Akuntansi Pengusaha Konveksi Kecamatan Tingkir Kota Salatiga

\begin{tabular}{lcc}
\hline \multicolumn{1}{c}{ Laporan/Catatan } & Jumlah & Persentase \\
\hline Barang jadi & 35 & $58,33 \%$ \\
Bahan baku & 30 & $50,00 \%$ \\
Penggajian/upah karyawan & 27 & $45,00 \%$ \\
Pesanan & 22 & $36,67 \%$ \\
Penjualan & 21 & $35,00 \%$ \\
Biaya produksi & 15 & $25,00 \%$ \\
Kehadiran pegawai & 8 & $13,33 \%$ \\
\hline Sumber: data primer diolah, 2013 & &
\end{tabular}

\section{SIMPULAN, IMPLIKASI DAN KETERBATASAN}

Dari hasil pembahasan dapat disimpulkan bahwa penggunaan informasi berpengaruh terhadap keberhasilan usaha pada UKM sentra konveksi di Kecamatan Tingkir Salatiga. Oleh karena itu, UKM sebaiknya menggunakan informasi akuntansi sebagai dasar dalam pengambilan keputusan bisnisnya agar diperoleh keputusan yang tepat sehingga dapat mendukung keberhasilan usahanya. Untuk menghasilkan informasi akuntansi, para pengelola UKM dapat memulainya dengan mencatat segala aktivitas bisnisnya, meskipun dengan cara yang sederhana. Jika catatan-catatan bisnis tersebut dikelola dengan baik, maka akan dapat menghasilkan informasi yang bermanfaat dalam pengambilan keputusan bisnis.

Dalam penelitian ini, jawaban responden atas pertanyaan kuesioner merupakan jawaban yang bersifat subyektif karena sangat tergantung dari pemahaman dan persepsi responden. Untuk penelitian yang akan datang diharapkan dapat menambah variabel lain yang memengaruhi keberhasilan usaha, seperti tingkat pengetahuan/pemahaman pengelola usaha atas akuntansi, minat pengelola usaha untuk melakukan pencatatan bisnis dan kepemilikan laporan keuangan.

\section{DAFTAR PUSTAKA}

Anthony, R. N., dan J. S. Reece. 1995. Accounting Principles. $7^{\text {th }}$ ed. USA: Irwin.

Belkaoui, A. R. 2000. Teori Akuntansi. Edisi Pertama. Jakarta: Salemba Empat.

BPS. 2012. Produk Domestik Regional Bruto Kota Salatiga Tahun 2011.

2012. Salatiga Dalam Angka.

Depdiknas. 2008. Kamus Besar Bahasa Indonesia. Jakarta: Balai Pustaka.

Deswira, E., M. Neldi, dan Lusiana. 2009. Analisa tingkat pemahaman pengusaha sektor usaha kecil menengah (UKM) terhadap informasi akuntansi pada 
laporan keuangan (studi empiris pada UKM yang terdaftar di dinas koperasi dan umkm kota Padang). UPI YPTK Padang.

Haryadi, D., E. E. Chotim, dan Maspiyati. 1998. Tahap Perkembangan Usaha Kecil: Dinamika dan Potensi Pertumbuhan. Bandung: Akatiga.

Holmes, S., dan D. Nicholls. 1988. An analysis of the use of accounting information by Australian small business. Journal of Small Business Management. Vol.26 No.20: 57-68.

Megginson, W. L., M. J. Byrd, dan L. C. Megginson. 2000. Small Business Management: An Entrepreneur's Guidebook. Boston: Third Ed. Irwin McGraw-Hill.

Pinasti, M. 2001. Penggunaan informasi akuntansi dalam pengelolaan usaha para pedagang kecil di pasar tradisional kabupaten Banyumas. Jurnal Ekonomi Bisnis dan Akuntans. Vol.3 No.1.

Pinasti, M. 2007. Pengaruh penyelenggaraan dan penggunaan informasi akuntansi terhadap persepsi pengusaha kecil atas informasi akuntansi: suatu riset eksperimen. Jurnal Riset Akuntansi Indonesia. Vol.10 No.3 (September): 321-331.

Saboet, H. V. 1994. Pentingnya informasi akuntansi dalam kehidupan manajemen. Majalah Ekonomi. No.11.

Sugiyono. 2010. Metode Penelitian Bisnis. Bandung: Alfabeta.

Suhairi. 2004. Persepsi akuntan terhadap overload standar akuntansi keuangan (SAK) bagi usaha kecil dan menengah. Simposium Nasional Akuntansi IX, Padang.

Suryana. 2003. Kewirausahaan. Jakarta: Salemba Empat.

Susanto, Y. K. 2008. Partisipasi anggaran, ketidakpastian tugas, penggunaan informasi akuntansi untuk evaluasi kinerja dan perilaku managerial. Jurnal Akuntansi dan Keuangan Indonesia. Vol.5 No.1.

Tania. 2008. Pengaruh pengalaman usaha dan pengetahuan akuntansi terhadap penggunaan informasi akuntansi pada usaha dagang di kota Salatiga. Skripsi.Fakultas Ekonomika dan Bisnis Universitas Kristen Satya Wacana Salatiga.

Utomo, W. P. 2010. Pengaruh persepsi dan penggunaan informasi akuntansi terhadap keberhasilan pengusaha tanaman hias di Surabaya. Skripsi. Universitas Pembangunan Nasional (UPN). Jawa Timur.

Undang-Undang Republik Indonesia Nomor 20 tahun 2008. Tentang Usaha Mikro, Kecil dan Menengah. 
Wahyudi, M. 2009. Analisis faktor-faktor yang memengaruhi penggunaan informasi akuntansi pada usaha kecil dan menengah (UKM) di Yogyakarta. Tesis. Program Pascasarjana Universitas Diponegoro. 


\section{Lampiran}

Tabel 10

Hasil Uji Validitas Penggunaan Informasi Akuntansi

Item-Total Statistics

\begin{tabular}{|c|c|c|c|c|}
\hline & $\begin{array}{l}\text { Scale Mean if } \\
\text { Item Deleted }\end{array}$ & $\begin{array}{l}\text { Scale Variance } \\
\text { if Item Deleted }\end{array}$ & $\begin{array}{c}\text { Corrected Item- } \\
\text { Total } \\
\text { Correlation }\end{array}$ & $\begin{array}{c}\text { Cronbach's } \\
\text { Alpha if Item } \\
\text { Deleted }\end{array}$ \\
\hline pia1 & 173,25 & 489,004 & 0,466 & 0,749 \\
\hline pia2 & 172,90 & 484,058 & 0,575 & 0,747 \\
\hline pia3 & 173,92 & 488,688 & 0,341 & 0,750 \\
\hline pia4 & 172,88 & 485,868 & 0,514 & 0,748 \\
\hline pia5 & 173,23 & 475,402 & 0,677 & 0,742 \\
\hline pia6 & 173,32 & 479,712 & 0,721 & 0,744 \\
\hline pia7 & 172,88 & 485,969 & 0,529 & 0,748 \\
\hline pia8 & 173,25 & 476,462 & 0,672 & 0,742 \\
\hline pia9 & 173,47 & 488,863 & 0,532 & 0,749 \\
\hline pia10 & 173,05 & 481,133 & 0,658 & 0,745 \\
\hline pia11 & 172,90 & 483,210 & 0,583 & 0,746 \\
\hline pia12 & 172,90 & 486,769 & 0,457 & 0,748 \\
\hline pia13 & 173,25 & 481,886 & 0,666 & 0,745 \\
\hline pia14 & 173,23 & 473,131 & 0,790 & 0,740 \\
\hline pia15 & 173,18 & 475,373 & 0,718 & 0,742 \\
\hline pia16 & 172,80 & 489,620 & 0,449 & 0,750 \\
\hline pia17 & 173,37 & 463,355 & 0,779 & 0,735 \\
\hline pia18 & 173,33 & 478,904 & 0,606 & 0,744 \\
\hline pia19 & 173,25 & 469,309 & 0,780 & 0,738 \\
\hline pia20 & 173,30 & 479,332 & 0,743 & 0,744 \\
\hline pia21 & 172,88 & 484,613 & 0,574 & 0,747 \\
\hline pia22 & 173,25 & 472,157 & 0,808 & 0,740 \\
\hline $\begin{array}{l}\text { PENGGUNAAN } \\
\text { INFORMASI AKUNTANSI }\end{array}$ & 88,60 & 125,702 & 1,000 & 0,932 \\
\hline
\end{tabular}


Tabel 11

Hasil Uji Validitas Keberhasilan Usaha

Item-Total Statistics

\begin{tabular}{llcll}
\hline & $\begin{array}{c}\text { Scale Mean } \\
\text { if Item } \\
\text { Deleted }\end{array}$ & $\begin{array}{c}\text { Scale } \\
\text { Variance if } \\
\text { Item } \\
\text { Deleted }\end{array}$ & $\begin{array}{c}\text { Corrected } \\
\text { Item-Total } \\
\text { Correlation }\end{array}$ & $\begin{array}{c}\text { Cronbach's } \\
\text { Alpha if } \\
\text { Item } \\
\text { Deleted }\end{array}$ \\
\hline ku1 & 57,43 & 87,504 & 0,315 & 0,850 \\
ku2 & 57,27 & 87,318 & 0,373 & 0,847 \\
ku3 & 57,10 & 80,939 & 0,724 & 0,827 \\
ku4 & 56,85 & 84,977 & 0,794 & 0,832 \\
ku5 & 57,42 & 81,196 & 0,687 & 0,828 \\
ku6 & 57,10 & 80,702 & 0,738 & 0,826 \\
ku7 & 56,85 & 84,469 & 0,805 & 0,831 \\
ku8 & 57,38 & 81,020 & 0,718 & 0,827 \\
ku9 & 57,03 & 83,592 & 0,588 & 0,835 \\
ku10 & 56,82 & 87,101 & 0,582 & 0,840 \\
KEBERHASILAN & 40,92 & 39,027 & 0,951 & 0,865 \\
USAHA & & & & \\
\hline
\end{tabular}

Tabel 12

Uji Reliabilitas Penggunaan Informasi Akuntansi

Case Processing Summary

\begin{tabular}{llll}
\hline & & $\mathbf{N}$ & $\mathbf{\%}$ \\
\hline Cases & Valid & 60 & 100.0 \\
& Excluded $^{a}$ & 0 & .0 \\
& Total & 60 & 100.0
\end{tabular}

a. Listwise deletion based on all variables in the procedure.

Reliability Statistics

Cronbach's

\begin{tabular}{ll} 
Alpha & N of Items \\
\hline .932 & 22
\end{tabular}


Tabel 12

Uji Reliabilitas Keberhasilan Usaha

Case Processing Summary

\begin{tabular}{cccc}
\hline \multirow{3}{*}{ Cases } & & $\mathbf{N}$ & $\mathbf{\%}$ \\
& Valid & $\mathbf{6 0}$ & $\mathbf{1 0 0 . 0}$ \\
\cline { 2 - 4 } & Excluded $^{a}$ & 0 & .0 \\
& Total & 60 & 100.0 \\
\hline
\end{tabular}

a. Listwise deletion based on all variables in the procedure.

Reliability Statistics

Cronbach's

\begin{tabular}{ll} 
Alpha & $\boldsymbol{N}$ of Items \\
\hline .865 & 10 \\
\hline
\end{tabular}

Tabel 13

Hasil Uji Regresi Sederhana

\begin{tabular}{|c|c|}
\hline Keterangan & Nilai \\
\hline \multicolumn{2}{|c|}{ Variabel: Penggunaan Informasi Akuntansi } \\
\hline Unstandardized Coefficients & 0,944 \\
\hline Standardized Coefficients & 0,305 \\
\hline \multicolumn{2}{|l|}{ Model Regresi } \\
\hline $\mathrm{F}$ & 5,933 \\
\hline Signifikansi & 0,018 \\
\hline$R^{2}$ & 0,593 \\
\hline Adjusted $R^{2}$ & 0,677 \\
\hline
\end{tabular}

